\title{
Food choices and environmental responsibility - protect the Baltic Sea
}

\author{
Virpi Vorne ${ }^{1)}$, Lila Patrikainen ${ }^{1)}$, Mari Kovero ${ }^{2)}$, Yrjö Virtanen ${ }^{2)}$, Matti Verta ${ }^{3)}$, Elina Lice ${ }^{4)}$, Karin \\ $\mathrm{Pai}^{5)}$, Liina Laumets ${ }^{5)}$, Liisa Lang ${ }^{5)}$ and Anne Aan ${ }^{5)}$ \\ ${ }^{1)}$ MTT Biotechnology and Food Research, P.O.Box 413, FI-90014 University of Oulu, Finland, \\ firstname.lastname@mtt.fi \\ 2) MTT Biotechnology and Food Research, FIN-31600 Jokioinen, Finland, firstname.lastname@mtt.fi \\ ${ }^{3)}$ Finnish Environment Institute (SYKE), P.O.Box 140, FI-00251 Helsinki, Finland, \\ matti.verta@ymparisto.fi \\ 4) University of Latvia, 19 Raina Blvd., Riga, LV 1586, Latvia, elina.lice@lu.lv \\ ${ }^{5)}$ University of Tartu, Ülikooli 18, 50090 Tartu, Estonia, firstname.lastname@ut.ee
}

'The Baltic environment, food and health: from habits to awareness - FOODWEB' is a project that aims to raise public awareness about the links between food quality and its origin, focusing on the Baltic Sea and its surroundings. Cultivation of food for humans and related production activities can impact negatively on the Baltic Sea, and aquatic food products from the Baltic Sea may cause problems to humans as a result of toxins in the marine environment. This is a circular problem in the Baltic ecosystem. The project is a part of Central Baltic IVA Programme 2007- 2013.

Finland, Estonia and Latvia take part in the Foodweb-project. The population is projected to grow in Finland and decrease in Estonia and Latvia. Regarding food consumption habits over the long term, the differences diminish among the countries and result in accordance with the assumption that social, economic and political changes influence eating habits. These changes might have had an effect on eating habits, especially increased consumption of meat.

Baltic Sea is generally considered one of the most polluted seas in the world. Agriculture and the food chain are largely responsible for eutrophication and pollution of waterways. Food consumption forms a significant part of the environmental load of households. In the project area we share the common concern of environment and food safety issues. Majority of the residents are concerned about toxicants found in food. Environmental aspect is coming more important when selecting the diet and increasing knowledge of food safety are taking into account in national food recommendations.

The eutrophication intensity varies among different foodstuffs: beef has the highest eutrophication intensity of all meats, about three times higher than that of pork, and seven times that of poultry. The eutrophication intensity of milk is relatively low. Nevertheless, the values associated with beef and milk are partly bound together, since a significant share of beef comes from milking cows. The eutrophication impacts of plants also vary among species: grain has the highest intensity of the plant-based raw materials.

The modelling shows that in Finland eutrophication can be reduced by about $7 \%$ by changing the food consumption habits towards a recommended direction, and currently private food consumption is not far from being in accord with recommendations. The major shift, about $7 \%$ units from protein to carbohydrates, was reached in the scenario by applying a reduction to all protein foods, and an increment to all carbohydrate foods. This is because the foods containing animal proteins have greater eutrophication potential than carbohydrate foods, and shifting from the use of protein foods to carbohydrate foods should influence the state of eutrophication. In countries with nutrient-extensive agriculture, like Estonia and Latvia, the agricultural sector needs to develop without increasing nutrient surpluses.

Key-words: Baltic Sea, Finland, Estonia, Latvia, food production, food chain, food consumption, nutrients, hazardous compounds, eutrophication. 


\section{Introduction}

The ecosystems of the Baltic Sea are unique, due to the low salinity. Both saltwater and freshwater species can adapt and thrive here. But this also makes the Baltic ecosystems sensitive to changes brought about through human actions. Eutrophication is currently one of the greatest problems, but also harmful compounds derived from human activity reach the Baltic Sea from many different sources. The Baltic Sea has been exposed to extensive use of chemicals since the beginning of industrialisation and its marine environment has a long history of contamination. Thus the Baltic Sea has often been referred to as the most polluted sea in the world.

Agriculture is responsible for a large share of the leached nutrients in the aquatic environment. High area-specific nitrogen and phosphorus loads are related to high rates of agricultural activity, including large-scale intensive livestock farming as well as the intensive use of fertilisers in specialised conventional farming systems.

Nowadays consumers demand safe food of high quality that has been produced with minimal adverse impacts on the environment. There is increased awareness that the environmentally conscious consumer of the future will consider ecological and ethical criteria in selecting food products. It is thus essential to evaluate the environmental impact and the utilisation of resources in food production and distribution systems for sustainable consumption.

The focus of the project is on the Baltic Sea and its surroundings. The project clarifies and interprets the relationship of people, food and environment in terms of how the state of the environment impacts on our food and safety, but also how human activities impact on the environment. Through research collaboration the partners will open up data sources for public use. The project will result in new tools to combine and interpret environmental impacts and environmentbased risks to food consumers.

The partners in the Foodweb-project are MTT Agrifood Research Finland, as the lead partner, the University of Tartu, the science exhibition centre AHHAA, the Finnish Environment Institute and the University of Latvia.

\section{Methods}

The methods are chosen to meet the challenges of linking environmental sustainability issues with the daily food choices of consumers, with particular reference to the Baltic Sea. Improving sustainability requires a thorough understanding of the relationships between the food we eat and all those activities that affect the Baltic Sea environment.

By using a visual method, the food plate model, we will build up a concrete and comprehensible interface for the consumers that demonstrates the sustainability aspects associated with their food choices. The main method that will be used to link food plate models with environmental sustainability measures is life cycle assessment (LCA). Material flow analysis (MFA) will be used as a complementary tool to expand the variety of the individual plate components, and to generate information on the potential risk elements in the food chains. MFA results will also be used to describe and explain the environmental impacts of the food chains of the regions under study.

\section{Results \\ Food production}

In Finland the food industry is the fourth largest branch of industry, in Latvia the second largest and in Estonia it accounts for about one fifth of the total production of processing industry. Meat production, as well as milk and dairy production, are the most important branches of industry in all three countries. In Finland the baking and in Estonia the beverage industries account for a large part of production and in Latvia milk production is the largest production sector ranked by value.

Fishing is also an important branch of industry. In the Baltic Sea, fish is caught both from the open sea as from coastal waters. The most significant fish species caught from the open sea are Baltic herring and sprat. In the coastal areas pikeperch, perch and whitefish represent a major part of the total fish catch. The most fished species differ between countries and fishing areas, but sprat and Baltic herring are commonly fished in Latvia, Estonia and Finland.

The structure of agriculture has been changing in recent years in the project area. In Finland and Latvia the number of farms is decreasing, but in Latvia the total area of agricultural lands and the size 
of the farms have increased. In Estonia the number of farms has grown, while farm size has decreased.

Finland and Latvia are entirely self-sufficient in milk and milk products, as well as in meat and eggs. In Estonia self-sufficiency in milk is about $161 \%$ and the degree in self-sufficiency in meat around $83 \%$. The degree of self-sufficiency in grain in all project countries varies from year to year depending on the harvest. Due to the northern location of these countries, most fruits and some vegetables are imported.

The main sector of Estonian agriculture is milk production, which is also the most important product from domestic animals in Finland. The selection of dairy products is wide in both countries: the selection varies from non-fat and semi-skimmed products to low-lactose and non-lactose milk products. Some of the products have been differentiated to conform to health trends: in Finland and Estonia customers can choose products that lower blood pressure and blood cholesterol, for example so-termed 'heart cheese'.

Organic and natural products are gaining more and more in popularity and the demand for organic food is increasing. The consumption of organic food varies among income and age groups and differs between young families and those households with older people.

\section{Dietary habits}

Dietary habits and food choices vary according to gender, age, area and income. Women eat more vegetables, fruits and berries in Finland and in Estonia than men, but in Finland men consume more bread and potatoes. In Estonia potatoes are consumed more among people with lower monthly income.

Low-fat milk is the most favoured milk among boys and men in Finland, whereas girls and women prefer skimmed milk. The total consumption of liquid milk products in Finland has decreased, while cheese consumption is increasing. Milk products are widely consumed by Estonians, regardless of age and sex, but $19 \%$ of males and over $25 \%$ of females do not normally drink milk.

Latvians consume cereal products (mostly bread) at a level of over $37 \mathrm{~kg}$, potatoes $88 \mathrm{~kg}$ and meat over $80 \mathrm{~kg}$ per annum on average. Fish consumption is considerably lower, about $12 \mathrm{~kg}$ per annum on average. The most consumed vegetables among Latvians are tomatoes, cabbage and cucumbers, and the most favourite fruits are apples.

In Finland the total meat consumption was $76.2 \mathrm{~kg} /$ capita in 2010. Pork was most popular, and it was consumed at $34.9 \mathrm{~kg} / \mathrm{capita}$. Nearly equal amounts of beef and poultry meat were consumed, $18.6 \mathrm{~kg}$ and $18.2 \mathrm{~kg} / \mathrm{capita}$ respectively.

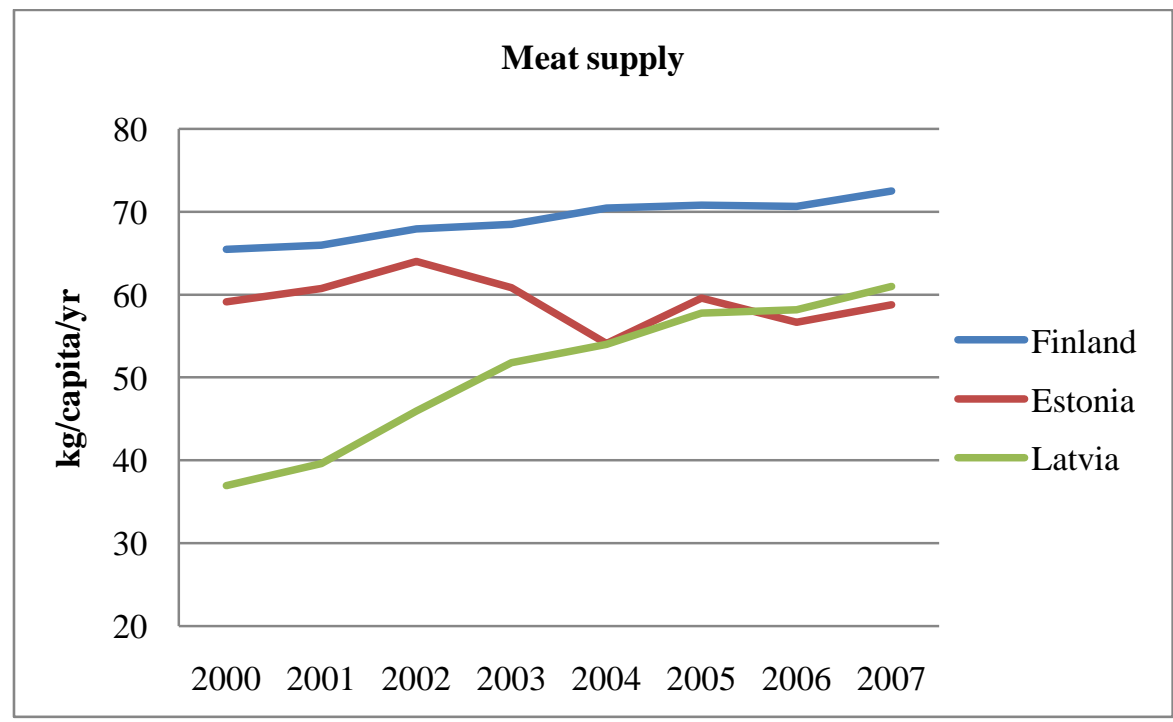

Source: FAOSTAT | ¡ FAO Statistics Division 2011

Figure 1. Timeline of the meat supply in Finland, Estonia and Latvia, 2000-2007. 


\section{Environmental impacts of the food chain}

Agriculture and the food chain are largely responsible for eutrophication and pollution of waterways. The share of agriculture in certain chemical emissions to the Baltic Sea in Finland, as well as of nitrogen and phosphorus leaching, has been estimated to be over $90 \%$. In Latvia it is estimated that more than $70 \%$ of the total nitrogen and more than $40 \%$ of the total phosphorus inland load is caused by various human activities, such as waste water discharge or runoff from agricultural land and forests.

In 2008 a total of 580600 tonnes of nitrogen and 25300 tonnes of phosphorus entered the Baltic Sea through waterways and more than half of both nutrients originated from diffuse sources. In 2008, 100000 tonnes of nitrogen and 5200 tonnes of phosphorus leached into the Baltic Sea from Finland, making Finland responsible for $17 \%$ of the total nitrogen load and $21 \%$ of the total phosphorus load. Estonia's nitrogen load was 46230 tonnes, accounting for $8 \%$ of the total load, with the phosphorus load being 1370 tonnes. This was $5 \%$ of the total load entering the Sea. Latvia's share of the total nitrogen load was 90000 tonnes, $15 \%$ of the total load, and the phosphorus load was 3000 tonnes (12\%) (1). Both $\mathrm{N}$ and $\mathrm{P}$ fluxes vary significantly from year to year depending mainly on hydrological conditions.

The nitrogen load appears to dominate the eutrophication potential of the Baltic Sea. Its contribution to the potential of the socio-economic activities was $73 \%$, which is 2.7 times that for the phosphorus load. In the contribution of agriculture the domination appears slightly higher, about 3.2 times that of phosphorus load. This suggests that the importance of nitrogen emissions may be underestimated in the current sustainability discussion concerning the Baltic Sea in the context of food chains.

The Finnish eutrophication impacts of animal production chains concentrate on feed raw material production. For beef, pork and milk, feed production contributes 95 to $96 \%$ of the total impact. For poultry and eggs the contribution is 86 to $93 \%$. The contribution of animal production (husbandry) is 4 to $5 \%$ and 7 to $13 \%$ respectively. The main causes of the eutrophication impacts are nitrogen and phosphorus runoffs from feed raw material production and the $\mathrm{NH}_{3}$ emissions from animal production.

Eutrophication intensities vary considerably among food raw materials. Table 1 shows eutrophication intensity values for Finnish food raw materials. The values were compiled with the help of the EIOLCA food chain model $(2,3)$. It should be noted that mass based intensities do not provide the whole picture of environmental impacts of foodstuffs because food has many other important properties, such as energy and nutritional capacity, which have to be taken into account.

Table 1. Formation of the Finnish eutrophication impact of raw material production in 2005.

\begin{tabular}{lc}
\hline Food raw material & $\begin{array}{c}\text { Eutrophication potential } \\
\mathrm{g} \mathrm{PO}_{4-} \text { eq/kg }\end{array}$ \\
\hline Beef & 51.5 \\
Pork & 15.4 \\
Poultry & 7.1 \\
Eggs & 16.1 \\
Milk & 3.3 \\
Meat (beef, pork and poultry) & 21.8 \\
Grain & 5.0 \\
Fruits and berries & 3.9 \\
Potato & 0.7 \\
Vegetables & 1.5 \\
Vegetarian average & 4.3 \\
\hline
\end{tabular}

In general plant-based materials have lower eutrophication intensities than animal based ones. On average meat is about five times more eutrophication intensive than plant raw materials. Among the meats, beef has the highest eutrophication intensity, about three times that of pork, and seven times that of poultry. Milk has a relatively low intensity. It should be noted, however, that the values for beef 
and milk are partly bound together as a considerable share of the beef comes from milk cows. Thus the method used to allocate the eutrophication emissions of milk cows reflects the intensities. In the Finnish model the shares allocated to beef and milk were $18 \%$ and $82 \%$.

Of the plant-based raw materials grain has the highest intensity, and variation is relatively of the same order as for animal based products. Grains are three times more intensive than vegetables, and seven times more intensive than potato in producing eutrophication impacts.

The modelling shows that in Finland eutrophication can be reduced by about $7 \%$ by changing the food consumption habits towards a recommended direction, and currently private food consumption is not far from being in accord with recommendations. The major shift, about $7 \%$ units from protein to carbohydrates, was reached in the scenario by applying a reduction to all protein foods, and an increment to all carbohydrate foods. This is because the foods containing animal proteins have greater eutrophication potential than carbohydrate foods, and shifting from the use of protein foods to carbohydrate foods should influence the state of eutrophication.

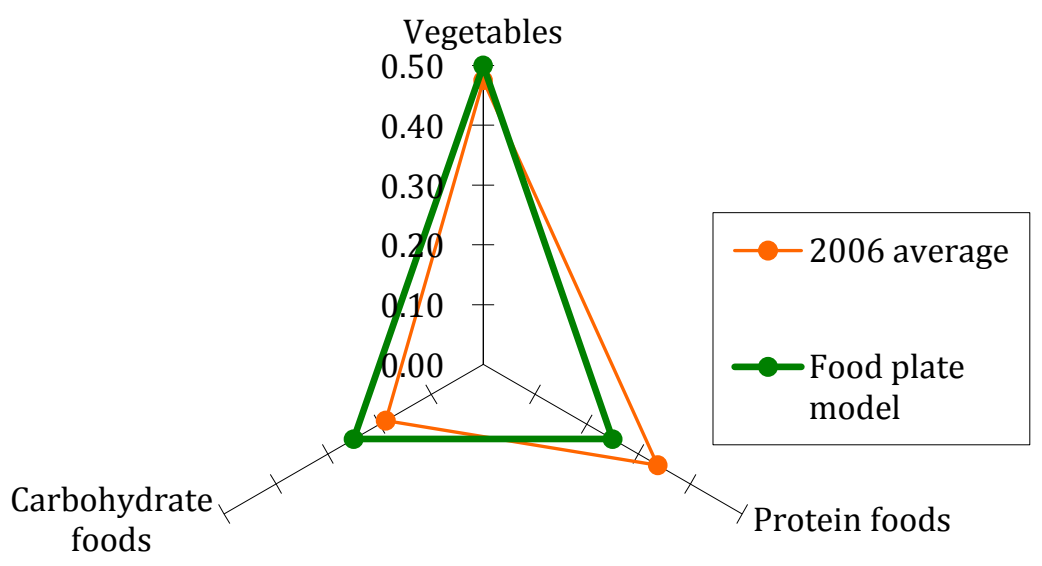

Figure 2. The idea of the diet scenario. The red triangle of 2006 private consumption is turned to the green triangle of recommended food plate.

\section{Hazardous compounds}

Knowledge of the levels of hazardous compounds in the Baltic Sea, and of their temporal changes, has increased substantially during recent years. Environmental concentrations and risks associated with several compounds that were used for long periods but have recently been highly regulated are in general well understood. These include many organic toxins (e.g.. PCB, DDT, HCB, HCH) and heavy metals (mercury, cadmium, lead, organic tin compounds). Further knowledge of some compounds used widely as flame retardants (PBDE, HBCD) or for their surface-active properties has been increasing. Examples of compounds of unintentional use, for which data are available, include dioxin compounds and polyaromatic hydrocarbons $(\mathrm{PAH})$, which are largely formed during combustion processes and are distributed extensively through atmospheric transport. Current knowledge of the state of the Baltic Sea regarding these compounds has been collected and assessed for the first time as part of the Baltic Sea Action Plan (BSAP) $(4,5)$.

PCBs, lead, mercury, caesium-137, DDT/DDE, TBT, benz(a)anthracene and cadmium were those compounds most commonly recorded among the compounds with the highest Contamination Ratios (CR, i.e. having highest concentrations in relation to target levels). Although several of the assessed compounds accumulate in the food chain the maximum levels in fish for human consumption are rarely exceeded. According to the Finnish Food Safety Authority, Evira (6), levels of dioxin and dioxin-like PCB compounds exceed the maximum stipulated limits in Baltic herring, salmon, sea trout, river lamprey and European flounder along the southern coast of Finland. However, the mean levels of dioxin and PCB, as well as of PBDE compounds, have decreased during the past 7 years. 


\section{Conclusions}

In Finland, Estonia and Latvia we share a common concern about the environment and food safety issues. Most residents are concerned about toxins found in food. During recent decades a variety of toxic compounds have entered the Baltic Sea as a result of human activity. The Baltic Sea is generally considered to be one of the most polluted seas in the world. The notorious pesticide DDT, industrially used PCB and dioxins degrade very slowly in nature and although their use has been banned, they still accumulate in the biota and accumulate at the top of the food chain. Heavy metals, such as mercury, copper and nickel, used by industry, are also found in the Baltic Sea. They accumulate on the seafloor from where they can migrate back into the food chain.

Volumes of dioxins, furans and dioxin-like PCBs in Baltic herring can exceed the acceptable daily limit. And frequent consumption of contaminated fish can lead to intakes above the maxima recommended. Increasing consumption of contaminated fish among risk groups is not desirable. Risk groups include people with low body weight, including children, pregnant or nursing women and groups with high natural consumption rates for fish, such as fishermen and their families.

The environmental aspect is becoming more important when selecting a diet, and increasing knowledge of food safety is taken into account in designing national food recommendations. Consumers prefer locally produced food and organic production is increasing. Despite this, consumers do not know that cultivation of food and related production activities might cause negative impacts on the Baltic Sea.

Eutrophication of the Baltic Sea is due to the excess nitrogen and phosphorus loads coming from land-based sources. The great majority of the nutrient load to the Baltic Sea is caused by agriculture, it being estimated that $75 \%$ of the nitrogen and $52 \%$ of the phosphorus come from agriculture and the livestock sector. The regional concentration of agricultural production and the growth in the sizes of animal farms have increased in the project area along with the increased demand and consumption of meat. Intensive farming also results in intensive fertiliser application and greater nutrient leaching to the sea. In Finland, agriculture is the most important source of coastal water nutrient loads.

The nutrient load of the Baltic Sea could be reduced simply by the surrounding populations eating less meat, especially in Finland. We can afford to this because we eat more animal products than is currently recommended. By changing our eating habits in a healthier direction and eating according to the official food recommendations, we could reduce the agricultural nutrient load by $7 \%$. This is not quite sufficient to cover the total reduction required by the BSAP, but would represent a significant step towards reducing the nutrient load of the Baltic Sea and would also benefit our own health. In countries with nutrient-extensive agriculture, like Estonia and Latvia, the agricultural sector needs to develop without increasing nutrient surpluses.

Reference List:

1. HELCOM PLC-Group. 2010. Waterborne loads of nitrogen and phosphorus to the Baltic Sea in 2008. HELCOM Indicator Fact Sheets 2010. Available at: http://www.helcom.fi/BSAP_assessment/ifs/ifs2010/en_GB/nutrient_load/

2. Virtanen, Y.; Hyvärinen, H.; Katajajuuri J.-M.; Kurppa, S.; Nousiainen, J.; Saarinen, M.; Sinkko, T.; Usva, K.; Virtanen, J.; Voutilainen, P.; Ekholm, P.; Grönroos, J.; Koskela, S.; Väänänen, S.; Mäenpää, I. 2009. Elintarvikeketjun ympäristövastuun taustaraportti. Laatuketju Available at: http://www.laatuketju.fi/laatuketju/www/fi/julkaisut/Ketjuvastuu kokonaisuus_15_12_2009.pdf

3. Virtanen, Y.; Kurppa, S.; Katajajuuri, J.-M.; Saarinen, M.; Usva, K.; Mäenpää, I.; Mäkelä, J.; Grönroos, J.; Nissinen, A. Carbon footprint of food - approaches from national input-output statistics and a food portion. Journal of Cleaner Production 2011, (19), 1849-1856.

4. Evira 2011. Itämeren kalan ja muun kotimaisen kalan ympäristömyrkyt: PCDD/F-, PCB-, PBDE-, PFCja OT-yhdisteet. Eviran julkaisuja 2/2011, Elintarviketurvallisuusvirasto Evira. Available at: http://www.evira.fi/files/products/1308559106186_eu_kalat_260511.pdf

5. HELCOM 2010. Hazardous substances in the Baltic Sea - An integrated thematic assessment of hazardous substances in the Baltic Sea. No. 120 B, Baltic Sea Environment Proceedings. Available at: http://www.helcom.fi/stc/files/Publications/Proceedings/bsep120B.pdf

6. Evira 2010. The chemical contaminants of foodstuffs and household water. Eviran julkaisuja 15/2010, Elintarviketurvallisuusvirasto Evira. Available at: http://www.evira.fi/files/products/1289807140773_kemialliset_vaarat_uudistettu_painos290910_web.pdf 